\title{
Plum Breeding Worldwide
}

W.R. O kie ${ }^{1}$ and D.W. Ramming ${ }^{2}$

Additional indeX words. Prunus domestica, Prunus salicina

Summary. The status of plum breeding around the world is reviewed. Two distinct types of plums are grown: Japanese-type shipping plums (mostly diploid hybrids of Prunussalicina Lindl. with other species) such as are grown in California, and hexaploid or "domestica" plums (P. domestica L.), which have a long history in E urope. In recent years there has been a resurgence of plum breeding outside the U nited States.

$\mathrm{P}$

lums are native across much of the temperate area of the world. In most areas early inhabitants long ago selected superior individuals of their local species. As Prunus breeders have made progress in improving plum quality and productivity, this native germplasm has been replaced by hybrid clones more suited to modern agriculture. Most plums in commercial production today are classified as J apanese (diploid) or European (mostly hexaploid) types.

\section{J apanese plums}

The ancestors of what we call J apanese plums actually originated in China. The term J apanese plum originally was applied to Prunus salicina (formerly P. triflora Roxb.) but now includes all the freshmarket plums developed by intercrossing various diploid species with the original species. These plums were initially improved in Japan and later, to a much greater extent, in the U nited States. Production in the U nited States is concentrated in California.

\section{Historical background}

Fortunately for the breeder, there are vast plum genetic resources although often they are not readily available ( $O$ kie and Weinberger, 1996; Ramming and Cociu, 1990). Prunussalicina cultivation goes back several thousand years in China (Yoshida, 1987) but plum has never been as commercially or culturally important in China as peach [P. persica (L.) Batsch.]. Plums in southern $C$ hina are concentrated in Fujian and Zhejiang, with $>20$ million trees and $\approx 200$ cultivars grown (Zhang et al., 1990).

Thanksto the following people for contributing to thispaper: J.H . Acker, B. Andersen, E. Bellini, L.A. Burmistrov, D. Cain, F. CampoDall'O rto, V. Cociu, T. D ej ong, E. D ela Bruna, J.-P. D ucroquet, H. D uval, W. H artmann, S.H . H jeltnes, R. H auagge, R.P. Jones, I. Kataoka, Y. Kobayashi, G. Lang, A. Liverani, S. M artelli, B. N akasu, V. N incetti, M . O jima, M . O osthuizen, S.A. Paunovic, M . Raseira, R. Renaud, S. Sansavini, R. Scorza, W. Sherman, C. Smith, S. Southwick, G. Tehrani, B. Topp, V. Trajkovski, A.D. Webster, G.V. E remin, M. Yamaguchi. The cost of publishing this paper was defrayed in part by the payment of page charges. U nder postal regulations, this paper therefore must be hereby marked advertisement solely to indicate this fact.

${ }^{1}$ Research horticulturist, U SD A-ARS Southeastern Fruit \& Tree N ut Research Station, 21 D unbar Road, Byron, GA 31008.

${ }^{2}$ Research horticulturist, U SD A-ARS H orticultural Crops Research L aboratory, 2021 S. Peach Avenue, Fresno, CA 93727. 
Plum culture in J apan and Korea is also very ancient, such that it is not possibleto tell if they were ever part of the native range for plums. T rees of improved $P$. salicina cultivars 'Kelsey' and 'Abundance' were introduced into the U nited States from J apan over 100 years ago. L uther Burbank intercrossed these and other imports with P. simonii Carr. and $\mathrm{N}$ orth American species, resulting in 'B eauty', 'Burbank', 'D uarte', 'E ldorado', 'Formosa', 'Gaviota', 'Santa Rosa', 'Satsuma', 'Shiro', and 'Wickson'. These plums formed the basis for the world's shipping plum industry, and some are still widely grown.

Pure P. salicina and related species have been little used as parents since Burbank's early hybridizations and few pure P. salicina clones are available outside of China. M ost of Burbank's plums are thought to descend from P. salicina, P. simonii and P. americana $M$ arsh. (H oward, 1945). In general, P. salicina contributed size, flavor, color and keeping ability; P. simonii contributed firmness and acidity (Gomez and Ledbetter, 1994); whereas the American species gave disease resistance, tough skin and aromatic quality. Burbank was fortunate in having available improved native material to supply these characters.

With the advent of Burbank's improved plumsthat werelargeand firm enough to ship long distances, a new industry developed in California and local industries in other states mostly died out. As local industries declined, breeding programswereclosed (Fig. 1). C alifornia-bred plum cultivars were tried around the world, but with the exception of a few places like C hile and some parts of I taly, they did not thrive as well as they did in C alifornia. As a result they were crossed with the local plums of the particular area.

In the southeastern U.S., the J apanese plums were crossed with the local $P$. angustifolia $M$ arsh. resulting in plumssuch as 'Bruce' and 'Six Weeks' (Wight, 1915). Although $P$. cerasifera Ehrh. is a progenitor of European plums, it is a diploid species crossfertile with Asian and American diploid species. These cherry plums have not been much used in modern breeding although chance hybridswith P. cerasi fera produced 'M ethley' in South A fricaand 'Wilson' in Australia. This species provides earliness, cold hardiness and probably self-fertility, but fruit size is small in currently available germplasm in North America.

U nfortunately for modern breeders, only a few of the improved native American selections are still available, since cultivation of native plumsis obsolete. $\mathrm{N}$ ew efforts to revive these local plum industries are underway in $K$ ansas with sandhill plum ( $P$. angustifolia) by Bill Reid and also by Richard $U$ va at

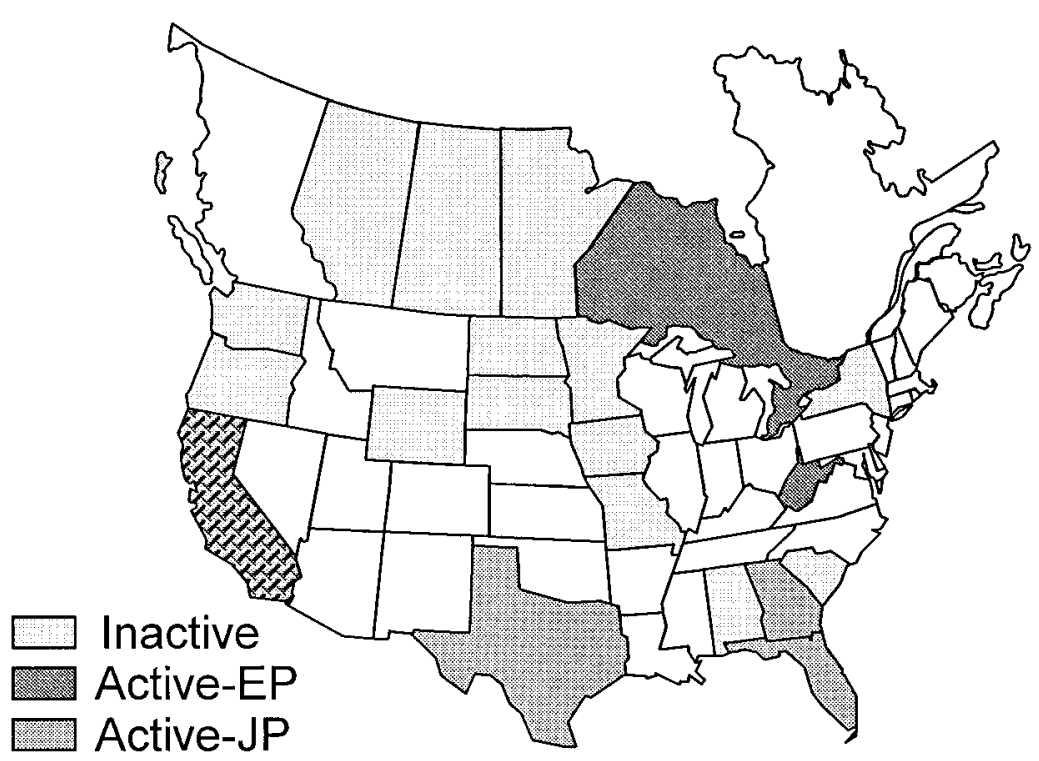

Cornell U niversity and others in $\mathrm{M}$ assachusetts with beach plum (P. maritima $M$ arsh.) for fruit and soil conservation. Adapted native species with poor fruit quality such as $P$. alleghaniensis Porter, P. geniculata $\mathrm{H}$ arper, P. mexicana S. Wats. and P. umbellata Ell., have apparently been unused by breeders until recently.

0 ther underused resources include the L ithocerasus subgenus, which is more graftand cross-compatible with plum than cherry (subgenus C erasus(Adans.) Focke), where it was formerly classified. Fertile hybrids of $P$. japonica Thunb. x plum have been reported from Japan (Kataoka et al., 1988) and produced at Byron, $\mathrm{G}$ a. The small-statured, pubescent-fruited species of the desert southwestern and western U nited States, are also littleused by breeders ( $O$ kie and W einberger, 1996). Plum interspecific hybridization is generally successful between diploids(Anderson and Weir, 1967; O kie and Weinberger, 1996). Plum-apricot (P. armeniaca L.) hybrids are easily made and carry flavor components and volatiles from both parents, plus some not found in either ( $\mathrm{Gomez}$ et al., 1993). A few plumcots have been introduced (see Zaiger and Bradford below) but low productivity has been a problem. Peachplum hybrids are easy to generate with bee pollination but are usually completely sterile.

\section{Modern breeding objectives and programs}

In most plum breeding programs, the principal objectiveisthedevelopment of plums that can be grown successfully in a particular locality and that can be marketed profitably. Trees must be productive, and must be resistant or tolerant to local problems, including hardiness in northern regions, low chilling requirements for buds in southern regions,
Fig. 1. Active and inactive J apanese plum (JP) or European plum (EP) breeding programs in the U nited States and $C$ anada. $C$ alifornia currently has both types of breeding programs. 


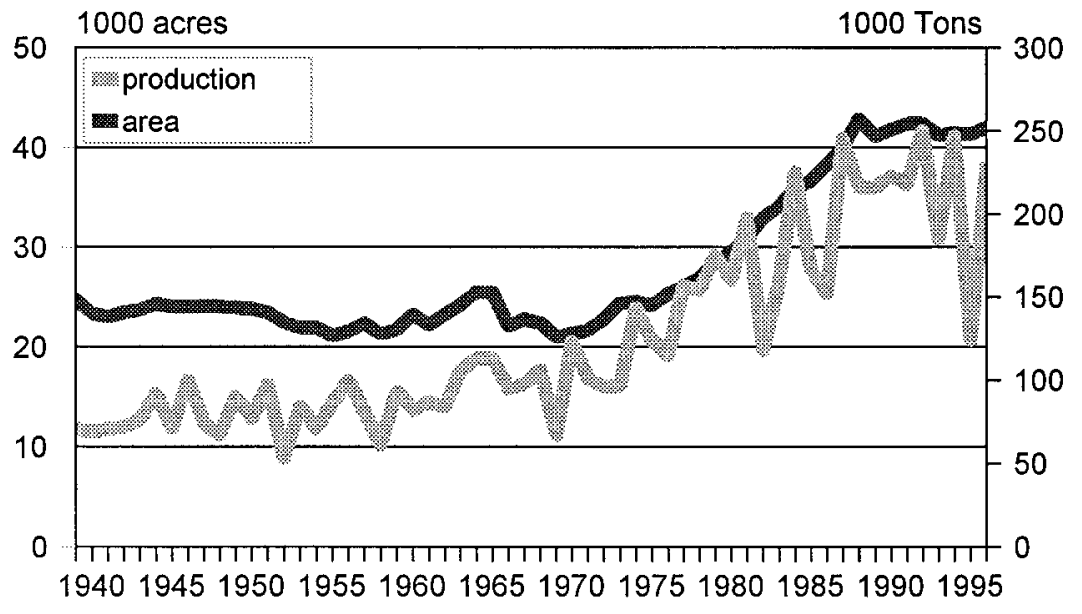

Year

Fig. 2. J apanese plum industry in C alifornia. Area and total production 1939-96; 1000 acres $=405$ ha, 1000 tons $=907 \mathrm{t}$.
Rosa', 'Eldorado', 'G aviota', 'Formosa' and 'Burbank' (Fig. 4).

The degree of consanguinity between the founding clones is not known because of Burbank's sketchy records. 'Kelsey' and 'Burbank' came directly from Japan. The others are hybrids, but could be closely related if only a limited number of parents were used from $P$. salicina and $P$. americana (H oward, 1945). Byrne (1989) reported the average coancestry of California plums to be 0.08 , about half that of eastern U .S. freestone peaches (Scorza et al., 1985).

D espite the limited number of founding clones in California plums, remarkable progress has been made in developing a series of large and firm plums suitable for longdistance shipping. Of the new plumsin Table 2 , only 'Showtime' and 'First Beaut' appear to be making a significant impact on the commercial industry. It is clear from the parentagesthat many introductionsareeither mutations or chance seedlings, rather than the result of planned hybridizations.

Breeding by U SD A atFresno, C alif., was begun by John S. Weinberger in the 1950s and is now under the supervision of $D$ avid Ramming. 0 ver 67,000 seedlings have been grown in that time with six releases. This program released 'Frontier' (1967); 'Friar' (1968), the predominant plum in the industry; 'C alita' (1968), for use in I taly; 'Q ueen R osa' (1972); 'Blackamber' (1980), another widely grown plum; and 'Fortune' (1990), a red plum. Black skin color became very popular with the introduction of 'Friar' because it did not show bruises and was very productive with large fruit.

$O$ verproduction and low prices of black plumshaveincreased theinterest in red plums. 'Fortune' was selected when black plums were gaining in popularity, and was not desired by the market until recently. Current breeding objectives include ripening from early to late in the season, and large, firm fruit with good shipping ability and eating quality. Red or black skin color and yellow or red flesh color appear to be the most acceptable, al-

Fig. 3. J apanese plum industry in C alifornia: top $\mathbf{2 0}$ cultivars showing their share of 1996 production. T otal 1996 production $=$ 228,000 tons $(207,000 \mathrm{t})$.

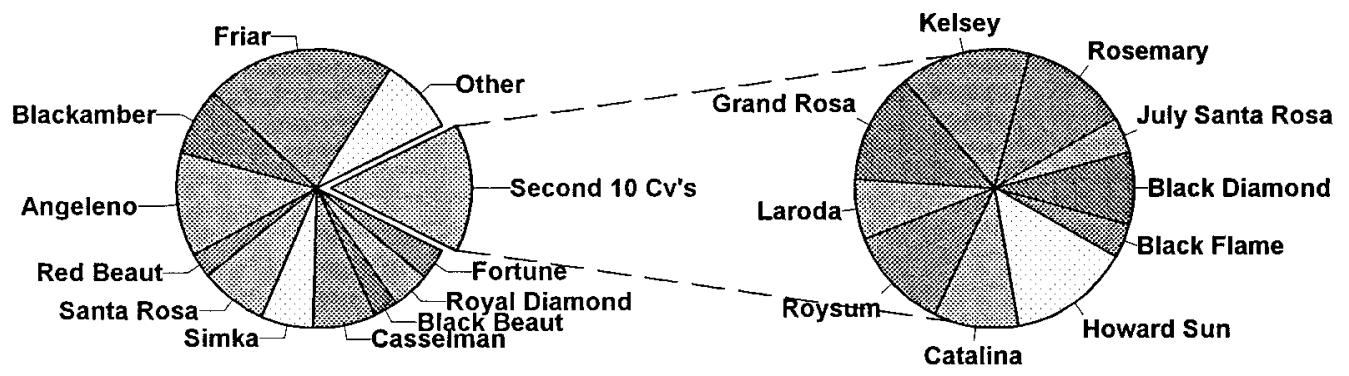


Table 1. M ajor C alifornia J apanese plums, ranked by 1996 production. O rigin, release date, and percentage of each is of the total trees planted in the last 6 years. T otal trees planted (based on nursery sales) $1991-96$ is 676,000 (from C alifornia Tree Fruit Agreement, 199096). Total production is 228,000 tons $(207,000 \mathrm{t})$.

\begin{tabular}{lcccl}
\hline & $\begin{array}{c}\text { Nursery } \\
\text { sales } \\
\mathbf{1 9 9 1 - 9 6} \\
\mathbf{( \% )}\end{array}$ & $\begin{array}{c}\text { Production } \\
\mathbf{( \% )}\end{array}$ & $\begin{array}{c}\text { Release } \\
\text { date }\end{array}$ & O riginator \\
Cultivar & 3.9 & 21.8 & 1968 & U SD A-Fresno \\
\hline Friar & 9.4 & 11.8 & 1967 & Garabadien \\
Angeleno & 1.5 & 7.9 & 1980 & U SD A-Fresno \\
Blackamber & 3.5 & 7.9 & 1906 & Burbank \\
Santa Rosa & 2.4 & 5.9 & 1959 & Kazarian \\
Simka & 7.1 & 4.5 & 1959 & Casselman \\
Casselman & 0.0 & 4.5 & 1989 & Kitahara \\
Royal Diamond & 0.0 & 2.9 & 1975 & Anderson \\
Black Beaut & 15.3 & 3.6 & 1990 & U SD A-Fresno \\
Fortune & 1.2 & 3.0 & 1965 & Anderson \\
Red Beaut & 6.3 & 2.2 & 1870 & Japan \\
Kelsey & 9.0 & 2.1 & 1982 & Chamberlin \\
H oward Sun & 1.9 & 1.9 & 1959 & Anderson \\
Grand Rosa & 0.0 & 1.9 & 1975 & Anderson \\
Rosemary & 0.1 & 1.8 & 1966 & Sumruld \\
Roysum & 2.2 & 1.4 & 1982 & Krause \\
Catalina & 1.5 & 1.2 & 1982 & Superior \\
Black Diamond & 0.0 & 1.0 & 1954 & U CD \\
Laroda & 0.0 & 0.6 & 1962 & Friesen \\
July Santa Rosa & 0.0 & 0.6 & 1985 & Superior \\
Black Flame & 0.0 & 1892 & Burbank \\
Wickson & 0.0 & 0.5 & 1993 & Zaiger \\
Autumn Beaut & 0.0 & 0.4 & 1982 & G erawan \\
Prima Rosa & 0.0 & 0.4 & 1980 & U SD A-Fresno \\
Freedom & 0.1 & 0.4 & 1986 & Zaiger \\
Autumn Giant & 0.0 & 0.3 & 1972 & U SD A-Fresno \\
Queen Rosa & 0.0 & 0.3 & 1904 & Burbank \\
Eldorado & 0.0 & 0.0 & 1992 & Wuhl \\
Show Time & 8.7 & 0.0 & 1990 & N eufeld \\
First Beaut & 3.7 & 8.6 & & \\
Other cultivars & 22.1 & & & \\
\hline
\end{tabular}

though green-skinned plums are shipped to Asian markets. Yellow-skinned typeswill need to be nonbrowning, to slow skin discoloration when bruised. Early ripening cultivars without bitter or acid skin and late season cultivars with desirable storagecharacteristics and that resist skin cracking areneeded. $\mathrm{H}$ igher sugar levels at early maturity stages would likely increase consumer preference for J apanese-type plums.

The U niversity of California at $D$ avis (U CD) began plum breeding in 1932 jointly with the USDA. Released were 'Burmosa' (1950), 'Redheart' (1950), 'L aroda' (1954), 'Redroy' (1954) and 'Q ueen Ann' (1954). 'Durado' was released by UCD alone in 1976. All except 'Redheart' and 'Redroy' have been important commercially. Thisprogram is no longer active in Japanese plum breeding.

Private breeders and growers in C alifornia have bred or selected (mostly) many important commercial plums. Fred Anderson released 'Red Beaut', 'Black Beaut', and 'Grand Rosa', (Table 1, Fig. 4) in addition to 'Amazon' (1960), 'Ebony' (1961), 'Grandoro' (1964), 'Andy's Pride' (1965), and 'Royal Garnet' (1981). H is work has been continued by Norman and Glen Bradford. Their newer plums include 'Black N oble', 'Early Beaut', 'June Beaut', 'Purple M ajesty', and 'Red Noble' (Table 2). They also developed plumcots 'Red Velvet' and 'R oyal Velvet'.

John Garabedian selected 'Angeleno' (Table 1), which is still increasing in importance. Selectionsfrom open-pollinated populations include 'Black Jewel' (1987), 'Gar Jumbo' (1987), 'Santa Rosa-2' (1987), 'Rancho 9-Golden' (1987), 'G ar Red' (1989), 'R ancho Cinco' (1989), and 'R ancho O cho' (1989).

Floyd Zaiger released 'Autumn Giant' (Fig. 4) and 'Betty Ann' (Table 2), as well as 


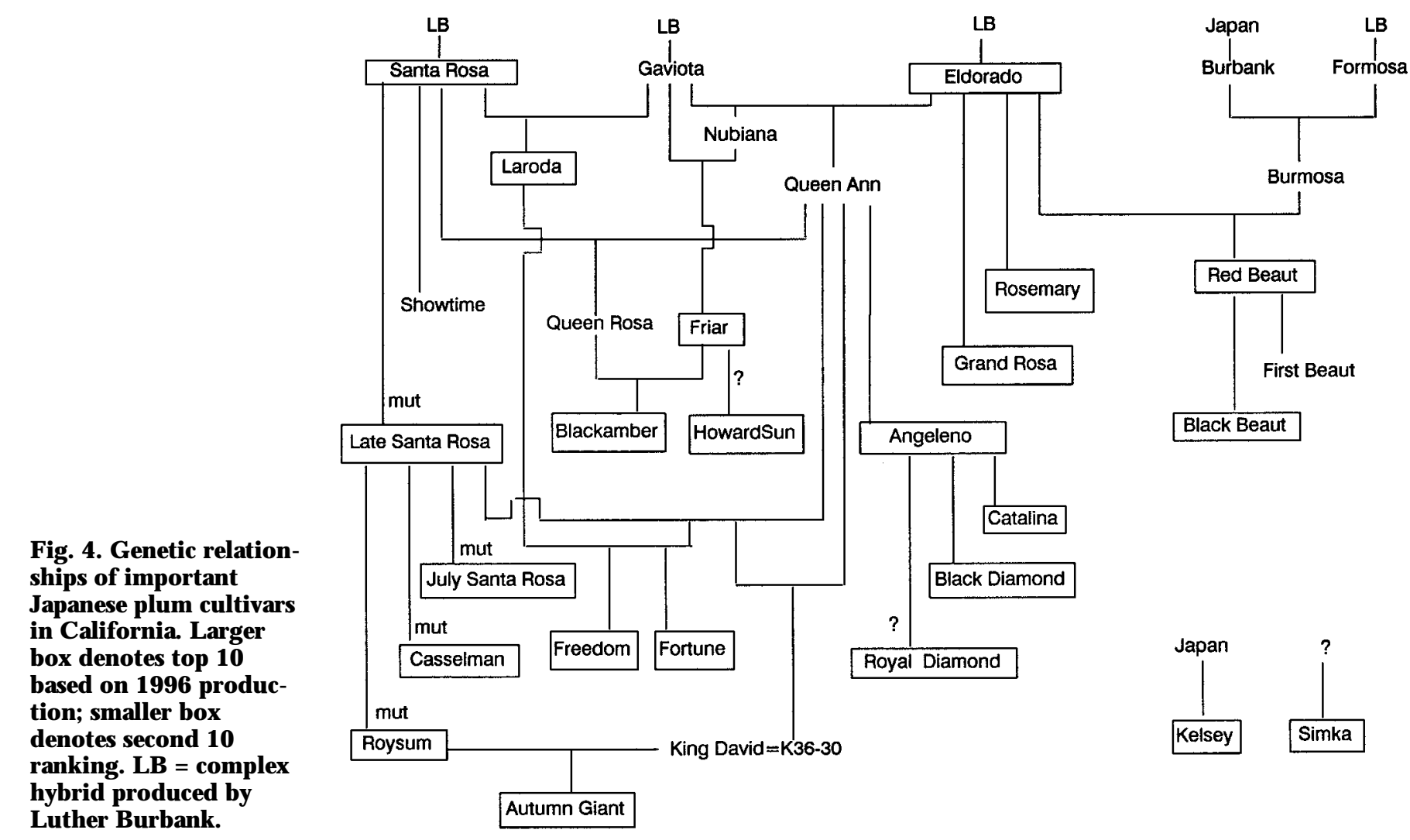

T able 2. Diploid plum and plumcot cultivars and selections since 1990. All from C alifornia except as indicated.

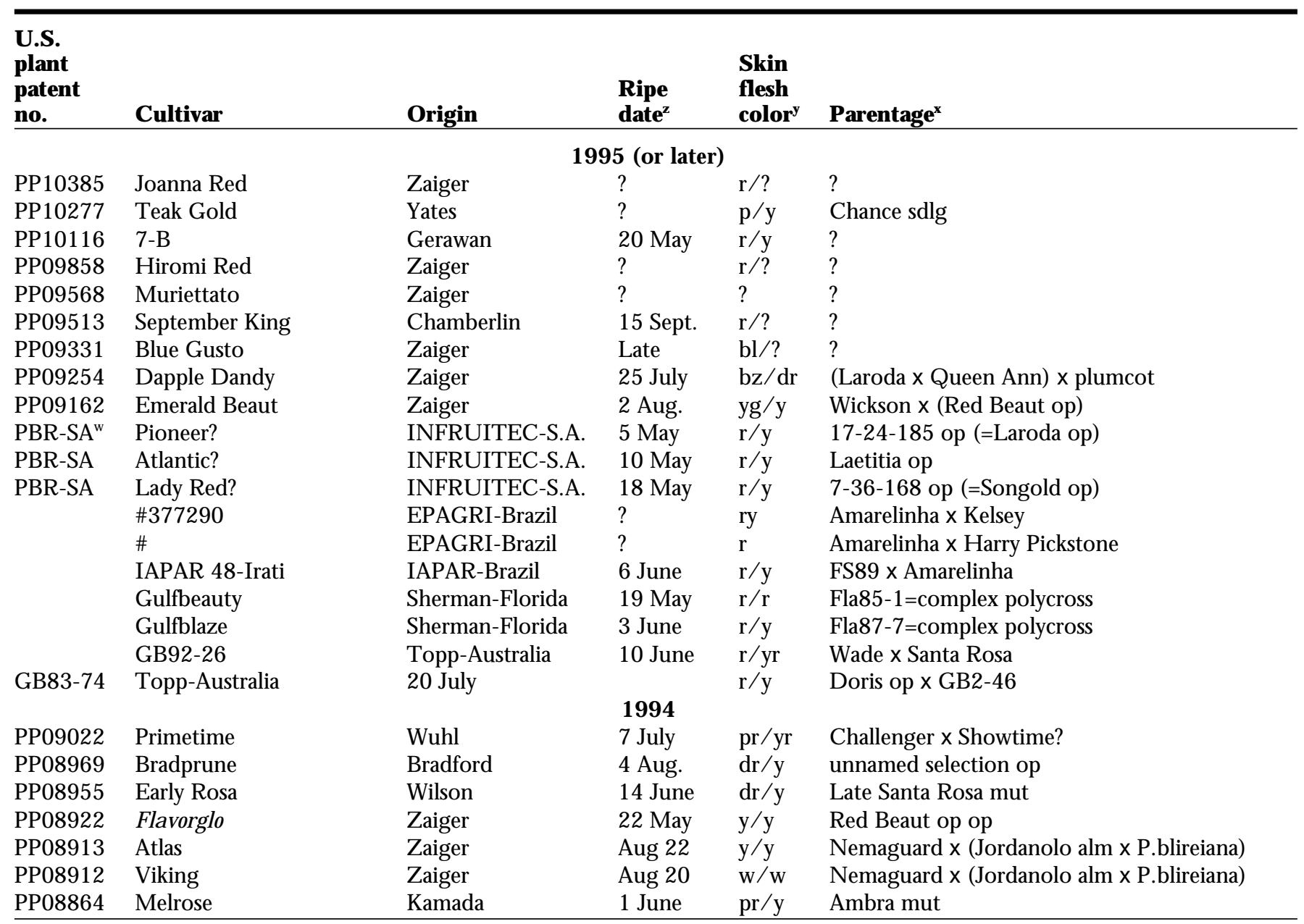


Table 2. (C ontinued) D iploid plum and plumcot cultivars and selections since 1990. All from C alifornia except as indicated.

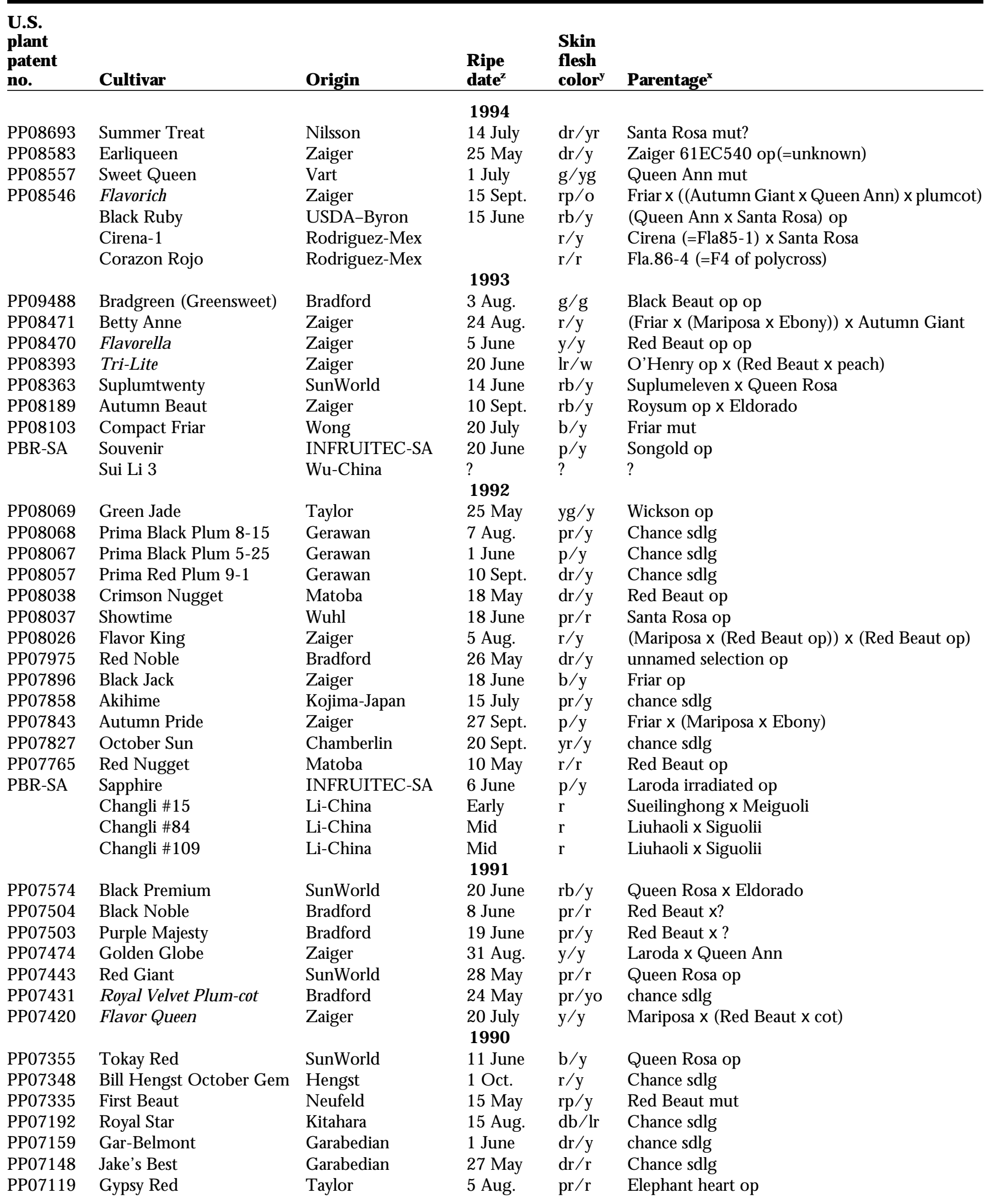

zRipe date for Santa Rosa on $\approx 31 \mathrm{M}$ ay in Fresno, Calif., area.

yColors ( skin and flesh): $b=$ black, $b z=$ bronze, $d=$ dark, $g=$ green, $I=$ light, $0=$ orange, $p=$ purple, $r=$ red, $w=$ white, $y=$ yellow.

$\times$ Seedling $=$ sdlg, open-pollinated $=$ op, mutation $=$ mut.

wPBR-SA = Plant Breeders Rights in South Africa. 
Fig. 5. G enetic relationships of important J apanese plum cultivars developed in the southern U nited States. Auburn U niversity cultivars in bold; U SDA-Byron cultivars in bold-italic. LB indicates complex hybrid produced by L uther B urbank.
'Rosemary' (1975), 'Rose Zee' (1984), 'D olly' (1987), 'Royal Zee' (1985), 'M id Red' (1986), 'Blue Giant' (1989), 'Golden Globe' (1991) and others. He has been a leader in development of complex interspecific hybrid rootstocks, such as 'Citation', 'Viking', and 'Atlas'. $\mathrm{H}$ e also has been very active in the development of plum-apricot hybrids and back crosses, such as 'Flavor Delight' and 'Flavor Supreme' and newer ones listed in Table 2, which are marketed using his trademarked terms "A prium" and "Pluot". I mproved taste is a current goal of their breeding. 'Flavorich', with black skin and firm, flavo rful, fine-textured orangeflesh, is quite promising for fruit quality.

B reeders] ohn Weinberger, C arlos Fear, Bruce M owrey, and D avid Cain at Sunworld I nternational (formerly Superior Farms) have patented 'Black Gold' (1980), 'Black Diamond' (1982), 'Black Torch' (1984), 'Sweet Rosa' (1984), 'Black Flame' (1985), and some newer ones (T able 2). Their program has been the largest of the private breeders, but recent reorganizations make future plum breeding uncertain (D. Cain, personal communication). As with most private programs, thereleasesare patented and often exclusively grown as well.

Tom Chamberlin (now with I to Packing) worked for H. P. M etzler's operation and selected plums from large lots of openpollinated seedlings of standard cultivars. $\mathrm{He}$ named 'Anna Sun' (1986), 'Ebony Sun' (1986), 'H oward Sun' (1987), 'M idniteSun' (1987), 'Scarlet Sun' (1988), and 'O ctober Sun' (1992).

SOUTHERN NORTH America. O bjectives in the so utheastern U nited States ( $G$ eorgia, A labama, T exas, Florida) include those of $\mathrm{C}$ alifornia plus additional disease resistance. Fruit firmness is somewhat less important because many local marketsare available. Resistanceis required to three primary diseases: bacterial

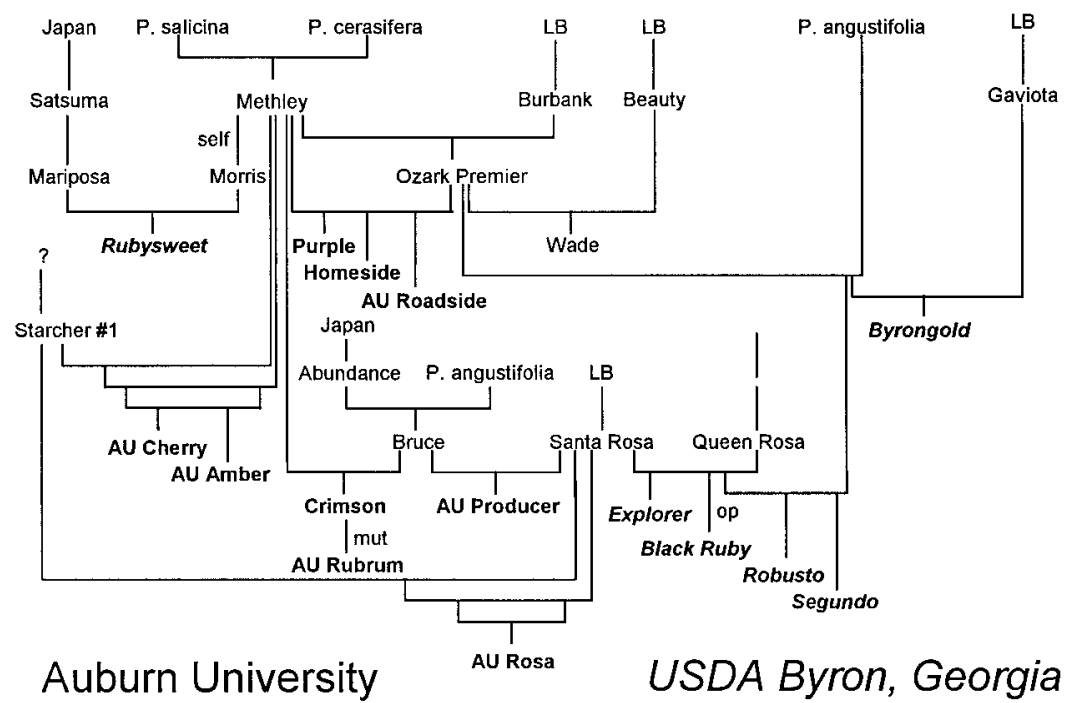

leaf spot, fruit spot and twig canker caused by $X$ anthomonas campestris pv pruni (Smith) $D$ ye; bacterial canker caused by $P$ seudomonas syringae pv syringae van $\mathrm{H}$ all; and plum leaf scald caused by X ylella fastidiosa Wells. The first two diseases are problems in many other countries that are trying to grow Japanese plums, such as Australia, N ew Z ealand, I taly, and South Africa (Topp et al., 1989). Leaf scald is also a serious problem in Argentina and Brazil. In general, later bloom is more desirable but regions such as Florida (Topp and Sherman, 1990) and parts of Texas, Austral ia, and Brazil require even lower chilling requirementsthan those common in J apanese plums. 'Frontier' is the only California plum grown to any extent commercially in the southern U nited States. 'Fortune' is also surprisingly productive and moderately healthy in Georgia, in contrast to the shortlived 'Blackamber'. 'Angeleno' survives fairly well although the fruit rarely hangs on the tree long enough to ripen properly.

Victor Prince began testing plums in 1958 at Fort Valley, Ga., and started making crossesin 1964 after theU SD A facility moved to Byron. M uch of the early seed for evaluating came from J ohn Weinberger in Fresno, $C$ alif. U nfortunately the large attractive $C$ alifornia plums would not survive in the humid climate of $\mathrm{Georgia}$. This California plum germplasm was crossed with southern varieties such as 'M orris', 'M ethley', 'Bruce' and thenativeP. angustifolia (Fig. 5). J im Thompson continued the plum breeding from 197286 , followed by W.R. O kie. Since 1964, $>40,000$ plum seedlings have been grown resulting in 'Robusto' (1980) and 'Segundo' (1984), early plums sold green; 'Explorer' (1980), a firm but unproductive black plum; 'Byrongold' (1985), a yellow plum with vigorous tree; 'Rubysweet' (1989), a high-quality blood-fleshed plum; and 'Black Ruby' (1994), a firm dark-skinned plum. Current goalsare to combinegood quality, large, firm fruit with consistent production on a healthy long-lived tree. About 4000 seedlings per year are grown, with most prescreened for vigor in the greenhouse. Most of the advanced selections are highly resistant to $X$ anthomonasand Pseudomonasbut only tolerant of leaf scald, which can ultimately kill them. Late blooming is needed to ensure a crop every year. O nly a few selections have most of these desirable characteristics, and for some seasons good selections do not exist. $M$ uch of this adapted plum germplasm is al so being used for rootstock development (for both peaches and plums) by T.G. Beckman.

A second long-term breeding program has been conducted at Auburn $U$ niversity in Alabama (Fig. 5), where J oe N orton began in 1955. Releasesare 'C rimson' (1973), 'Purple' 
(1973), 'H omeside' (1975), 'AU -Producer' (1977), 'AU -R oadside' (1984), 'AU -C herry' (1989), 'AU -Amber' (1989), 'AU-Rosa' (1989) and 'AU-Rubrum' (1989). While most have improved disease resistance, only 'AU -R ubrum' has sizeand firmness ad equate for commercial shipping. B reeding has been discontinued with the recent retirement of Norton.

Limited breeding was done at several other locations in the eastern U.S. (Fig. 1). In the 1940s the M issouri State Fruit Experiment Station released 'Bonnie', 'Brilliant', 'M arvel', 'O x-H eart', 'O zark Premier', 'Redbud', and 'Twilight'. 'Ozark Premier' has been widely grown in thesoutheastern $U$ nited States for its large fruit size but tree health of it and its first-generation offspring (Fig. 5) is marginal. 'Wade' was released in 1974 by Clemson U niversity in South Carolina and also has been grown in the southeastern $\mathrm{U}$ nited States. Both these programs are now closed. 'M orris' (Fig. 5), another popular southern plum, was also released in 1974 from T exas A\& M U niversity. Plum breeding there has been renewed by $D$ avid Byrne who has been intercrossing U SDA-Byron plums with othersto develop cultivarswith aslightly lower chilling requirement. Byrne has been a leader in the use of isozymes and genetic markers to distinguish cultivars, verify parentages, and determine the relationships between plum species.

Wayne Sherman at the U niversity of Florida has been developing low-chill plums for several decades, intercrossing U SDAByron selections, low-chill importsfrom Taiwan (such as ' $\mathrm{H}$ ungyou $\mathrm{Li}$ '), and local selections including P. angustifolia. T wo old, discarded selections have been propagated by local nurseries under the names 'Gulf Gold' and 'G ulf Ruby' (Sherman and L yrene, 1985). The newest Florida selections have much better fruit sizeand quality than locally grown plums, but susceptibility to plum leaf scald remains a concern (Sherman et al, 1992; Topp and Sherman, 1990). With the release of 'Gulfbeauty' and 'Gulfblaze' in 1997, the work is being phased out.

A modest plum breeding program at Chapingo, M exico, was initiated in the early 1980s by J orge Rodriguez-A. Themajor goal isdevelopment of large, firm-fleshed cultivars adapted to subtropical climates. Two lowchill cultivars were released in 1994, 'Cirena 1 ' and 'C orazon Rojo', both developed from Florida selections.

Northern North america. None of the public breeding programs developing coldhardy plum hybrids are still active (Fig. 1). $M$ any cultivars were released before 1950 , especially from South D akota and M innesota Agriculture Experiment Stations, using the most cold-hardy plum species: P. nigra Ait., $P$. besseyi Bailey, and P. salicina (from $M$ anchuria) (Kadir and Proebsting, 1994). 'Sapa' (=P. besseyi $x$ 'Sultan') and its many hybrid offspring, although poor in quality, arewidely adapted. Thesehybridsare often called "cherry plums", the same term used for P. cerasifera, and are now used more for rootstock development than for fruit production. The $U$ niversity of $\mathrm{M}$ innesotabreeding program, long inactive, recently released an old selection as 'Alderman'.

Plum crosses were made at I owa Agricultural Experiment Station but the only hybrid released was 'Lantz' in 1958. N ew York and Ontario, Canada, have also had J apanese plum breeding as a minor adjunct to the European plum breeding. 'Vanier', was released by $\mathrm{O}$ ntario in 1984 . N either program has continued J apanese plum breeding. The most important northern cultivar has been 'E arly G olden', a chance seedling found in 0 ntario $>50$ years ago but still widely grown. Other programs developing coldhardy stone fruit were the $\mathrm{H}$ orticultural $\mathrm{Ex}$ periment Station, Brooks, Alberta; Dominion Experiment Station, $M$ orden, $M$ anitoba; U SD A N orthern G reat Plains Field Station, $M$ andan, N.D.; and the U niversity of Saskatchewan, Saskatoon, Saskatchewan (O kie and Weinberger, 1996). M odest efforts to improve northern plums have been continued by private individuals and Brian Smith at the U niversity of Wisconsin at River Falls.

South America. Brazil has five J apanese plum breeding programsin traditional plumproducing areas, with chill requirementsranging from 200 to $500 \mathrm{~h}$. An older program at the Instituto Agronomico de Campinas under Fernando Campo-Dall'O rto and M ario O jima developsred-fleshed plumsadapted to the warm areas around Sao Paulo $(\approx 200 \mathrm{~h}$ of chilling). The primary disease problem is leaf rust. L ow-chilling J apanese plums have been released: 'C armesim' (1973), 'R osa Paulista' (1978), 'G rancuore' (1978), 'Gema-de-ouro' (1979), 'Golden Talisma' (1979), 'Rosa M ineira' (1983), 'J anuaria' (1985), 'Kelsey$31^{\prime}$ ' (1987) and 'C entenaria' (1989). M ost of these are seedlings of 'Kelsey Paulista', which was a local selection of 'Kelsey' ( 0 jima et al., 1992).

Roberto $\mathrm{H}$ auagge at the Instituto Agronomico de Parana in Curitiba, Parana, Brazil has a large $(30,000$ seedlings) but young program to combine resistance to leaf scald and bacterial spot with moderate chill (200 to $500 \mathrm{~h}$ ). Byron germplasm tested there shows good disease resistance but is not low-chill enough for reliable cropping.

In Santa Caterina, breeder Emilio D ela Bruna with EPAGRI (Empresa De Pesquisa 
AgropecuariaE Extensao R ural) in U russanga, Brazil has produced 20,000 seedlings from crosses of local plums such as 'Amarelinha' with imports like 'Kelsey' and 'M ethley'. The chilling requirement here is only $250 \mathrm{~h}$, less than that needed at a similar but smaller program run by Jean-Pierre Ducroquet in Videira (D ucroquet, 1994). Both need high levels of disease resistance to bacterial spot and leaf scald.

At EM BRAPA/ CPACT (Empresa Brasileira dePesquisaAgropecuáária/ Centro de Pesquisa Agropecuáária de Clima Temperado ) in Pelotas, Rio Grande do Sul, Brazil, Bonifacio $N$ akasu and $M$ aria Raseira have a small program to develop $300 \mathrm{~h}$ plums with resistance to bacterial spot and leaf scald ( $N$ akasu et al., 1981). Releasesinclude' $P$ luma 7' (='TheFirst' $x$ 'Santa R osa') and 'Pluma 2' ( $=$ 'Satsuma' open-pollinated).

OTHER SOUTHERN hemisPHeRe. In SOuth A frica plum breeding is done by $\mathrm{Chris} \mathrm{Smith}$ and Michael Oosthuizen at the Infruitec $C$ entre for Fruit T echnology. Their program has released a series of plums to satisfy their shipping industry. The goal is development of large-fruited plums with resistance to bacterial spot and bacterial canker, and the ability to store without internal breakdown. Storage ability of four weeksiscrucial to exporting the fruit by ship. Plums also need a moderate chilling requirement to enhance crop set in lower chilling areas of South Africa. Releases are 'Songold' (1972), 'H arry Pickstone' (1973), 'Reubennel' (1978), 'Redgold' (1979), 'L aetitia' (1985), 'C elebration' (1989), 'Sapphire' (1992) and 'Souvenir' (1993). Pending releases are in Table 2. 'C elebration' is their first black-skinned cultivar. These cultivars represent a slightly different gene pool for breeders because of the use of local cultivars 'M ethley' and ' $G$ olden King' as parents (Fig. 6). Several of these plums are being used as parents in Brazil and elsewhere.

Plum breeding in Australia, under the direction of Bruce T opp at the Granite Belt $\mathrm{H}$ orticultural R esearch Station in Q ueensland, was begun in 1967. 'Q ueensland Bellerosa' ( ='Burbank' $x$ 'SantaRosa') and 'Q ueensland Earlisweet' (='Early Jewel' x 'E arly Gem') were named in 1988. The latter plum is descended from local cultivars with at least partly P. cerasifera parentage. I mpending releases are listed in Table 2. Their goals are large sized, early ripening, high quality fruit suitable for export to Asia, combined with resistance to bacterial spot and blemishesdue to summer rainfall (Topp and R ussell, 1989). M ost of the latest research on bacterial spot resistance in plum hasbeen doneby Topp. An intense prescreening is done in the greenhouse to eliminate the most spot susceptible

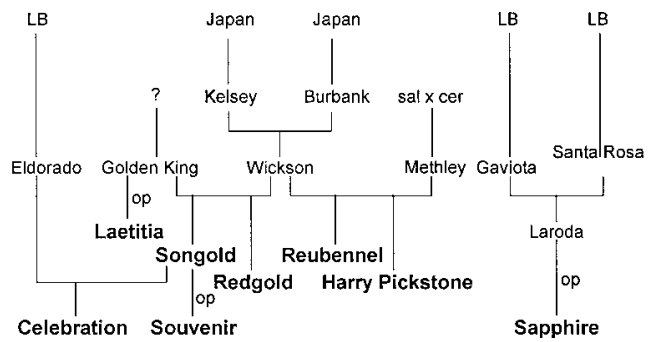

Fig. 6. G enetic relationships of important $J$ apanese plum cultivars developed in South Africa (in bold). L B indicates complex hybrid produced by $L$ uther B urbank. G olden King may have come from Australia.

seedlings before they are planted to the field (Russell et al., 1992; T opp et al., 1993). This is a large program, with over 30,000 seedlings now in the field.

In $\mathrm{N}$ ew Zealand, M ike $\mathrm{M}$ alone of $\mathrm{H}$ ortResearch has begun a small plum and plumcot breeding program to develop disease-resistant cultivars suited for local useand export. Existing seedlingsare open-pollinated populations from 'Flavorella' and other plumcots, as well as from local plum selections.

EASTERN EUROPE AND ASIA. I n J apan, most new cultivars have comefrom private so urces. $\mathrm{M}$ ost prominent isthe program of M r. O hishi, who has released ' $O$ hishi- $N$ akate' and ' $O$ hishiwase' among others. Yukio Kanno recently released 'White Q ueen', 'Beniryouzen', and 'Ryozenwase'. Other new cultivars are 'Shichiro' and 'Pararu'. M uch of the 9900 acres ( $4000 \mathrm{ha}$ ) of commercial production is from U.S. cultivars such as 'Santa Rosa', 'Sordum' (='Sultan'), and 'B eauty'. 'M ethley' is also popular. Masami Yamaguchi at the Fruit Tree R esearch I nstitute in T sukuba has a small plum breeding program, with two releases, 'T sukuba N o. 4' and 'T sukuba No. 5' (both= 'Sordum' x 'N ishida').

Breeding in China is apparently limited to the colder regions. A large germplasm collection has been made for plums under Zhang Jia-Yan at Liaoning. In Changchun, Jilin, Li Feng has developed several selections, including Changli \#15, Changli \#84 and Changli \#109 (Table 2) (Li, 1993). A second program in $\mathrm{H}$ eilongjiang Province has released a new cold-hardy plum 'Sui L i 3' (Wu, 1993). Breeding to improve $P$. humilis $\mathrm{Bge}$ for size and quality is being done by $\mathrm{Du}$ Junjie at Taigu, Shanxi (D u et al., 1993).

In Korea, the $\mathrm{N}$ ational $\mathrm{H}$ orticultural Research Institute in Suweon began a small program in the late 1980s, but no new cultivars have been released. The principal objective in the plum breeding program is the development of new early-ripening cultivars that have high sugar content and large fruit. 
Primary parents are also the most popular cultivars: 'O ishi-wase', 'Formosa', 'Santa Rosa', and 'Soldam'.

Plum breeding began just 5 years ago in Thailand with goals to develop 100 to 400 chill hour cultivars with good size, flavor and firmness and long shelf life. Parents include 'Gulf Ruby', Australian selections, and Taiwanese selections. The work is cooperative between the Royal Project Foundation and Kasetsart U niversity, under the direction of U naroj Boonprakob. A program with similar objectives was also started at the Taiwan Agricultural Research Institute in Wu-Feng by Wen Jen-C hie, but currently managed by Shyi-Kuan $\mathrm{O} u$.

In Siberia and Krasnodar Territory of the U SSR, cold hardiness is the primary goal (Burmistrov, 1992). Despite the relatively lower chilling requirements of many J apanese plums, midwinter tree and bud hardiness is quite high, often higher than for peaches (Q uamme et al., 1982). N ew cultivars include 'Altaiskaya Yubileinaya', 'Katunskaya', 'Kulundinskaya', 'Amurskaya Rannaya', 'R assvet Rannii', 'Tikhookeanskaya', 'U rozhainaya Dalnevostochnaya', and 'Khabarovskaya Rannaya'. These types are extremely cold hardy. In Krymsk, E remin has had a large program using interspecifics to develop cold-hardy plums. Winter-hardy, disease-resistant diploid releases include 'Kubanskaya Kometa' ('Kuban Comet'), 'Puteshestvennisa' ('Traveler') and 'N eberjaiskayaE arly'. Several of thesediploid cultivars have recently been imported into theU .S. for testing. A new program in L atvia has named threehybrids of $P$. ussuriensisK ov. $\&$ Kost. $x$ cerasifera (Table 2) (I kase, 1992).

Western eURope. Japanese plum breeding in Europe is relatively new but will be important as demand continues to increase for thelarge-fruited J apaneseplums. Antonino $\mathrm{N}$ icotraat I stituto Sperimentale Frutticoltura in Rome, I taly has selected a compact-sized tree with good fruit using $X$-ray treated pollen. Smaller trees are desirable to reduce production costs. A small program at Forli, I taly, under Alessandro Liverani has also selected some dwarf types. He has crossed California plums with local types. Goals are large size, a range of skin and flesh colors, bacterial spot resistance, and good eating quality. Silverio Sansavini and Salvatori $M$ artelli aim to develop plums for the area around Bologna, I taly where spring weather makes pollination difficult and productivity low. I nitial crosses were between local myrobalan cultivars (for reliable cropping) and J apanese plums. Backcrosses to the J apanese side are needed to improve fruit quality and size, and extend the season. The program of Elvio Bellini and V. Nincetti at Florence,
I taly, islarger in size. Thegoalsare to develop self-fertile, late-blooming plums with high quality, particularlyyellow-skinned types. Selffertility would improve productivity and facilitate genetic analyses. Their most valuable cross has been Black Gold x Burmosa, and several thousand seedlings of this combination have been produced. To overcome problems with seed germination, all the seeds are embryo-cultured.

$\mathrm{H}$. D uval at Institut $\mathrm{N}$ ational de la Recherche Agronomique in A vignon has begun plum breeding for southern France, where the plum production area is now $\approx 6200$ acres (2500 ha) (D uval et al., 1994). Poor weather during pollination is a major problem, so improved productivity is a primary goal. Resistance to plum pox (sharka) virus and European stonefruit yellows(ESFY, formerly called chlorotic leaf roll) phyto plasma is also important. Japanese plums such as 'Red Beaut' seem less susceptible to plum pox, although they can serve as sources of inoculum. H owever, $C$ alifornia plums are very susceptible to ESFY. Prunuscerasifer a seems to be resistant to ESFY, but first generation selections of Afaska ( $=P$. cerasifera) $\times \mathrm{H}$ arry Pickstone have been too small in the first generation. The project is still evaluating advanced selections and introduced varieties, but no new hybrids are being made.

\section{European plums}

European plums (P. domestica) are generally adapted to cooler regions, and may be eaten fresh or processed in a variety of ways. U.S. production is mainly in California, but small amountsarealso grown in I daho, Washington, O regon, $\mathrm{M}$ ichigan, and $\mathrm{N}$ ew York for both fresh and canned use. European plums with a high enough sugar content so that they can be dried unpitted are called prunes. In some countries the term prune refers to the dried product; elsewhere the term refers to the fresh fruit as well. Most pruneproduction in Californiaand elsewhere is of 'French Prune', also called 'Prune D'Agen', 'Petite Prune' or 'Prune D'Ente'. In contrast to J apanese plum production in the $U$ nited States, the California prune industry continues to expand.

\section{Historical background}

Prunus domestica has been the most important plum species historically. Crane and Lawrence (1956) thought it originated in Asia M inor as a triploid hybrid between $P$. cerasifera and the tetraploid P. spinosa L., which then doubled to produceafertilehexaploid. More recently, Eremin (1991) proposed $P$. spinosa resulted from $P$. cerasifera $x$ P. microcarpa C.A. M ey. whileP. domestica is 
P. spin osa x P. cerasifera macrocarpa. N ewer cytological work (R eynders-Aloisi and Grellet, 1994) suggested P. spinosa itself carries the genome from $P$. cerasifera plus a second one from an unknown ancestor that was not $P$. microcarpa. Thus $P$. domestica may be descended from polyploid forms of $P$. cer asifera, which has a long history of local use and selection across the continent, and occurs in a range of fruit color and palatability. Although sometimes used for drying and processing, most wild P. spi nosa fruit are bitter. It ranges from Scandinavia across Europe to Asia M inor.

Plums have been a commonly grown garden tree in E urope since the first century A.D. Several cultivars known in 1597 are still grown, such as 'Reine Claude'. O ne of the earliest plum breeders was Thomas Andrew Knight in England, whose work encouraged nurseryman Thomas Rivers who released 'Early Rivers' in 1834, followed by 'Early Transparent Gage', 'C zar', 'M onarch' and 'President'. By the early 1900s, plum breeding was being carried out at research stations at L ong A shton (later E ast M alling) and J ohn Innes (Roach, 1985). In other European countries local selections of the older cultivars were made and became established, but little formal breeding was done until later.

\section{Modern breeding objectives and programs}

Whereasmost J apaneseplumsareshipped for fresh, dessert use, E uropean Plums may be eaten fresh, canned, dried, processed for cooking use or distilled into brandy (Ramming and Cociu, 1990). Each use requires different selection criteria in the breeding program. Current programs seem to favor dessert use, with only a few for dried fruit (T able 3).

North america. O ne of the oldest European plum breeding programs is that of the $\mathrm{H}$ orticultural Research Institute of O ntario in Vineland, O ntario, Canada, which was under the supervision of $\mathrm{G}$. T ehrani until his recent death. $\mathrm{O}$ bjectives are to develop highquality dessert plums ripening in late August to complete a sequence of plums ripening from July to $O$ ctober. Selection criteria are cold hardiness, productivity, and blue color (T ehrani, 1990). They released six fresh market cultivars: 'Valor' (1967), 'Verity' (1967), 'Vision' (1967), 'Veeblue' (1984), 'V oyageur' (1987) and 'Victory' (1992), all of which are commercially planted in O ntario. 'V oyageur' provides a self-fertile, early-ripening plum extending the season before 'Stanley'.

The $\mathrm{N}$ ew York Agricultural Experiment Station at Geneva has also been an important source of plum cultivars. Releases include 'H all' (1923), 'A merican M irabelle' (1925), 'Stanley' (1926), 'Albion' (1929), 'I roquois'
(1966), 'M ohawk' (1966), 'O neida' (1966) and 'Seneca' (1972). 'Stanley', the most successful, is grown around the world, and is the basis of the current $\mathrm{N}$ ew York industry. $\mathrm{N}$ ew releases are 'Castleton', 'Longjohn' and 'Polly', all dessert plums (Table 3). A few other selections from Geneva are still under test by Bob Andersen and may be released, but no breeding is expected in the future. These selections include a ' $M$ irabelle'-type for processing (N Y 858), a 'D amson'-type for jam (NY58.911.1), two fresh market plums (NY1456, an improved 'Yellow Egg'-type and NY77.610.1), two selections for infant food puree and canned or frozen uses (NY6 and $N$ Y9) and two supersweet prune plums for fresh eating (NY71.385.1 and NY71.387.1).

$U C D$ has renewed plum breeding under the direction of Ted Delong to develop prunes ripening before and after 'I mproved French Prune'. N ew cultivars must resemble and perform like 'I mproved French' in order to fit standard production practices for dried fruit. Self-pollinated seedlings of 'French Prune' display uniformly poor fruit quality, thus it is being crossed with other parents. 'Emperor' was recently released for dessert use, but no new prunes are near release.

At Prosser, Wash., U SD A and later Washington State U niversity conducted limited breeding from 1949-75. $\mathrm{H}$ arold Fogle and later Tom Toyama made crosses to replace 'E arly I talian' with higher fruit quality and a range of ripening times. Primary parents were 'Italian', 'Parson', 'Stanley', and V33016 (='Imperial Epineuse' $x$ 'I talian'). Currently $G$ reg $L$ ang is conducting final testing on the remaining few selections, with PP6975-2 and PP7524-7 slated for release (T able 3). Fogle continued this work when he transferred to Beltsville, Md., in 1963. Recently one of Fogle's selections was named 'Bluebyrd' by R alph Scorza at U SD A-K earneysville, W.Va. (Table 3), where a limited program of plum development continues. Scorzaand colleagues havealso genetically engineered plums highly resistant to plum pox virus ( $R$ avelonandro et al., 1997).

The M issouri State Fruit Experiment Station released three European plums in 1947: 'Bluebell', 'Bluefre', and 'R adiance'. 'Bluefre' has become an important plum in O ntario, Canada. No other American programs have developed European plums except for 'Gardner' (1923) from the O regon Agricultural Experiment Station in 1923 and 'H ildreth' (1982) from U SD A in Cheyenne, Wyo.

Western europe. Breeding efforts in Europe have increased in recent years. At IN RA in Bordeaux, France, the goals of $R$. R enaud are to develop a series of drying prunes and 
dessert plums that are adapted to French conditions. Cross-fertile prunes are needed that produce fruit with similar traits to improve cross-pollination and maximize fruit set. Fresh plums are needed that ripen before and after 'ReineClaude', with equal or better flavor and firmness, and high productivity (Renaud and R oy, 1990). I nitial results of the breeding were three new prune cultivars'Primacotes', 'Lorida', and 'T ardicotes'. Selections of 'French Prune' have also been made available-Prune d'Ente GF626, GF642, GF707, GF303, and 'Spurdente', the last of which, obtained through irradiation, ripens earlier, is more precocious, and needs less pruning. 'Fermareine' is the first of a series of dessert plums that will be released (H ilaire and Renaud, 1985; R enaud, 1994). The success in irradiation has led to a similar program to irradiate' R eine Claude' to obtain a selection with low vigor and precocious bearing. A new program seeks to develop selections similar to ' $\mathrm{M}$ irabelle de $\mathrm{N}$ ancy' that will spread the ripening season and have larger fruit size.

At $\mathrm{H}$ orticultural Research International

Table 3. E uropean plum and prune cultivars and selections since 1990. R ipening shown by date and relative to 'Stanley'.

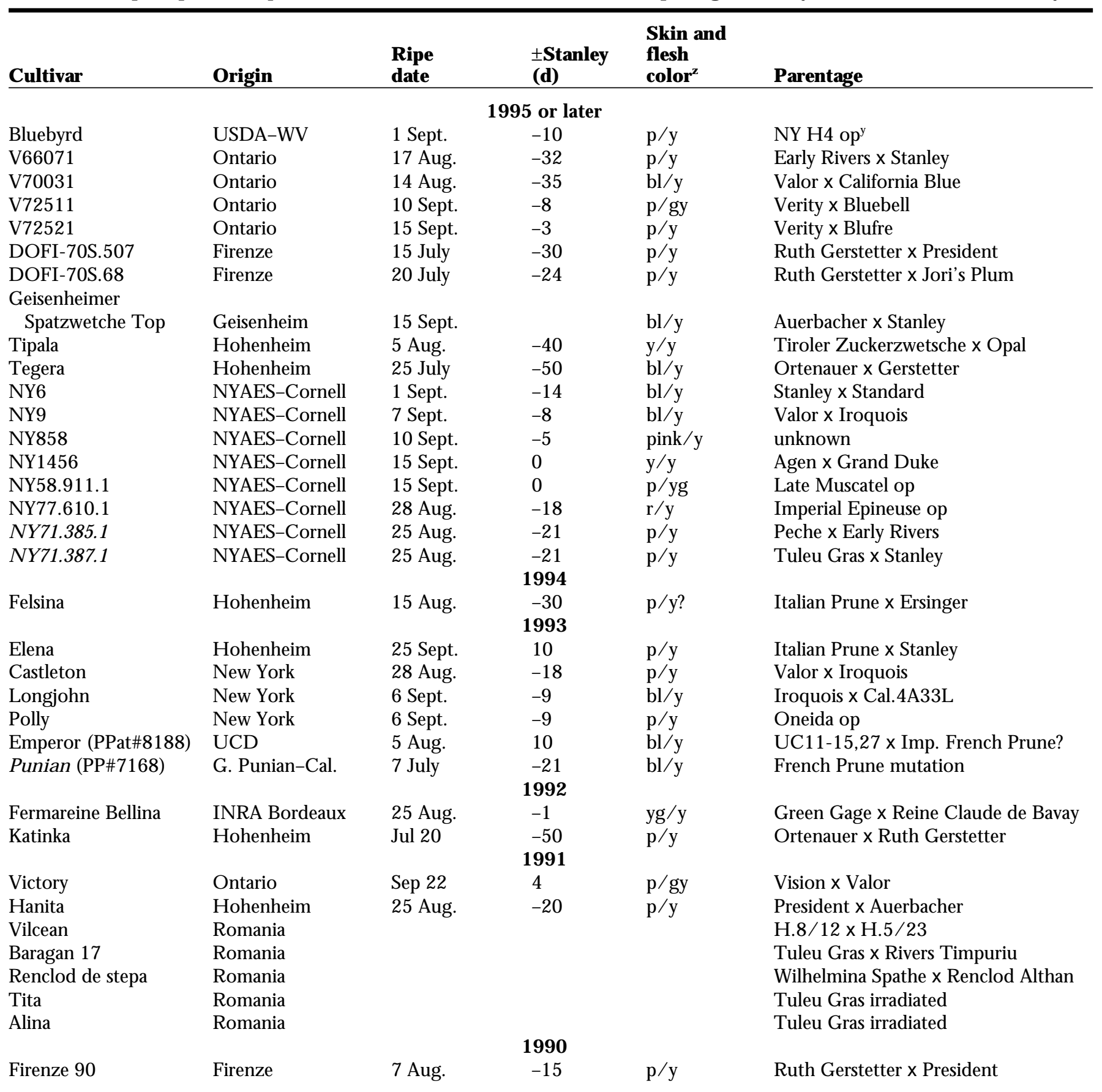

${ }^{z}$ Colors (skin/ flesh): $b l=$ blue, $g=$ green, $p=$ purple, $r=$ red, $y=$ yellow.

yo pen-pollinated $=$ op. 
in East $\mathrm{M}$ alling, Kent, U .K., goals included late bloom to improve productivity, large fruit size [ $>1.6$ inches $(40 \mathrm{~mm})]$ ) and dessert quality. With consumers now less interested in processed plums, there is increasing demand for red, purple, and blue freestone fresh-market plums. Resistance to pests and disease will become more important as usage of pesticides is restricted. Primary disease problems are bacterial canker [Pseudomonas syringaepv mor sprunorum (W ormw) Young, D ye and Wilkie], silver leaf [ $C$ hondroster eum purpureum (Pers.:Fr.) Pouzer] and fruit rot (M onilinia frutigena $\mathrm{H}$ oney). A long juvenility period (4 to 6 years) slows the progress toward these goals by increasing generation time (J ones and Wilson, 1987). 'Avalon' and 'Excalibur', released in 1988, are vigorous plums with large, high quality fruit suitable for the dessert market, but self-incompatibility and poor weather at bloom limit their productivity. This breeding program is suspended for the moment as R. P. Jones has retired, but selection testing is continuing.

In Italy, E. Bellini at Florence began breeding in 1970 to develop early-ripening dessert plums with large, high quality fruit and vigorous productive trees (Bellini et al., 1990). Resistanceto biotic and abiotic stresses is also important. 'Ruth Gerstetter' has been the most important parent. The first release of the breeding program was 'Firenze 90 ', a very productive, firm, high-quality plum for fresh market. $O$ ther advanced sel ectionsspread the season, and are highly productive on very healthy trees. Other smaller programs at Rome, Bologna, and Forli are aimed at developing very early-ripening plums, particularly with semicompact tree size. Bologna also has a small program for development of drying plums.

Germany revived plum breeding in 1980 at the $U$ niversity of $\mathrm{H}$ ohenheim. G oals of $\mathrm{W}$. $\mathrm{H}$ artmann are to extend the season, improve quantity and quality, and have resistance to plum pox (H artmann, 1994). 'Stanley' has been a good parent to transmit tolerance to plum pox. H artmann (1991) has made clonal selections of the tolerant 'Buhler Fruhzwetsche' with a range of ripening dates to develop aseries of plumsthat can be grown in sharka-infested areas. Six hybrid cultivars have also been released for fresh fruit or processing (Table 3), most of which are selffertile. 'T egera' isrelatively resistant to brown rot for an early plum. The breeding program at Geisenheim recently released a damson type plum (Table 3).

In 1984 a new breeding program began in Switzerland under M. Kellerhals at the SwissFederal Research Station in W adenswil. Their goals include develo pment of early and late ripening plums for fresh use, particularly with high quality, long shelf lifeand $M$ onilinia laxa ((Aderh. \& Ruhl.) H oney) resistance (Kellerhals and Rusterholz, 1994).

In Sweden, morecompact treehabit and high cold hardiness are sought by Viktor Trajkovski at Balsgård. Fruit goals include high sugar and Vitamin $C$ and less need for thinning. Releases include 'I ve', ' $\mathrm{H}$ erman', 'M eritare', 'J ubileum' and 'A nita', and dwarf plums 'Violetta' and 'M adame'. The program has recently expanded to include diploid breeding.

M odern plum breeding in Norway began at the Agricultural U niversity in As in 1979 and moved in 1990 to the Research Station at $\mathrm{N}$ jøs. Breeding has continued intermittently since 1934. Current goals are high quality, large attractive fruit with good shelf life, and high annual cropping. 'Edda' wasreleased in 1983. Theprogramscurrently serves Denmark and Finland as well by producing seedlings for evaluation in their climates ( $H$ jeltnes, 1994).

Eastern europe and asia. Eastern Europe has a long history of plum breeding, with many cultivars released. Similar goals are important in Yugoslavia, Romania, Czechoslovakia, and Bulgaria. Since much of the plum production is dried or processed into brandy and other products, high soluble solids are essential.

In Yugoslavia, resistance to rust [Transzschelia pruni-spin osae(Pers.) D iet.] is also needed. Since the program began in 1947, Yugoslav breeders have released plums for fresh market use such as 'Cacak's Early', 'Cacak's Beauty', 'Cacak's Best', 'Cacak's Fruitful' and 'C acak's Sugar'. These cultivars show good resistance to red leafblotch (Polystigma rubrum (Pers.) D.C.) and to rust. All but the last have the local cultivar 'Pozegaza' as a parent (Paunovic et al., 1975; Paunovic, 1988). Several clonal selections of 'Pozegaza' haveal so been disseminated. Their newest hybrid releases are prunes ' $V$ aljevka' (1985) and 'J elica' (1986), and 'Valerija' (1987) for dessert use (O gasanovic et al., 1994). R ecent breeding for sharka resistance has been most successful using as parents 'L argeSugar Prune' and 'Zh'ItaButilcovidna' (Rankovic et al., 1994).

Breeding in Romania began in 1950. Since then 20 cultivars have been named. They provide a succession of dessert plums from July through September. The best are 'Tuleu Timpuriu' (1967), 'G ras Ameliorat' (1970), 'C entenar' (1978), 'Silvia' (1978), 'D iana' (1981), 'I alomita' (1981), 'Pitestean' (1981), 'C arpatin' (1981), 'M inerva' (1984) and 'Flora' (1989). N ewest cultivars are 'Baragan 17', 'Renclod de stepa', 'Vilcean', 'Tita', and 'Alina' (Cociu, 1993).

Institutional plum breeding in Czecho- 
slovakia traces back to the 1960 s. Recently, several selections from the I nstitute for F ruit and $O$ rnamental Plants at Bojnice have been tested. BO II/ 65, a prune, ripensa week after 'Stanley'. Prunes BO III/ 77 and BO IV/ 39 ripen $\approx 3$ to 3.5 weeks before 'Stanley'. Since 1988 breeding for plum pox resistance has been done at the Research and Breeding Instituteof Pomologyat H olovousy (D robny, 1990).

There are at least 10 breeding programs in the former USSR (Burmistrov, 1992). They require cold hardiness, modest tree size, self-fertility, and productivity (8 to 10 years of harvest). In the more southern zones larger size [ $>1$ oz $(30 \mathrm{~g})]$, higher sugar content $(>13 \%)$, purple fruit, and earliness are desired. In more northern zones these fruit quality parameters become less important as hardiness becomes the overriding consideration. Resistance to sharka, Polystigma, and $M$ onilinia rot are also important. The breeding program at Krymsk has released 'KubanskayaL Legenda' ('Kuban Legend') and 'Kavasskay Vengerka' ('C aucasian $\mathrm{H}$ ungarian'), which are self-fertile, cold hardy, and suited for drying. 'Kurbansky K arlik' ('Kuban D warf') is a good-quality, self-fertile, dwarf tree [up to $10 \mathrm{ft}(3 \mathrm{~m})$ ]. 0 ther new cultivars grown in the southwestern region are 'VengerkaKrupnaya', 'K ubanskayaR annaya', and 'Sochinskaya Yubleinaya'. In the westcentral region of the U.S.S.R., newer cultivars are 'Bogatyrskaya', 'Evrazia 21', 'Volzhskaya Krasavitsa', 'Renklod Kuibyshevskyi', 'Renklod Kolkhoznyi', 'Pamyat Timiryazeva', 'Skorospelka', and 'Yaichnaya Sinaya'.

\section{Conclusions}

As better cultivars are becoming available, interest in plums isincreasing, especially in light of the increased importance of local production. The wide range of fruit flavors and colors, ease of consumption, and apparent heal th ben efits associated with consumption of highly colored fruits make plums a desirable product for local sales wherever they can be grown. B reeding programs having to select for local adaptation and disease resistance as well as fruit type, face a greater challenge. It will take time to develop a series of plums with high levels of size, firmness and quality that ripen over an extended season. However, there is an opportunity in these programs to use the diverse germplasm to develop plumswith much moreintenseflavor than is commonly available. Fortunately the trend towardsfewer plum breeding programs in the U nited States is offset by the increase in international programs. To maintain the progress made in plum improvement, efforts to collect and preserve germplasm are needed to help plum breedersincreasetheir use of the wide, diverse array of Prunusthat exists but is often not accessible. Such germplasm will allow the development of high-quality plums adapted to an even wider range of environments. Some of these complex hybrids will also provide a new generation of rootstocks for stone fruits.

\section{Literature cited}

Andersen, E.T. and T.S. Weir. 1967. Prunus hybrids, selections and cultivars at the U niversity of M innesota Fruit Breeding Farm. M inn. Agr. Expt. Sta. Tech. Bul. 252.

Bellini, E., G. Giannelli, and E. Picardi. 1990. Genetic improvement of European plum: Promising selections from Florence (in Italian). Riv. Frutticoltura 6:25-29.

Burmistrov, L.A. 1992. Plum breeding in several zones of the U SSR. Fruit Var. J. 46:26-27.

Byrne, D.H . 1989. Inbreeding, coancestry, and founding clones of $\mathrm{J}$ apanese-type plums of $\mathrm{C}$ aliforniaand thesoutheastern $U$ nited States. J . Amer. Soc. H ort. Sci. 114:699-705.

California Tree Fruit Agreement. 1996. Annual report. Calif. Tree Fruit Agreement, Sacramento.

Cociu, V. 1993. Forty years of plum breeding in Romania. Fruit Var. J. 43:63-67.

Crane, M.B. and W.J.C. Lawrence. 1956. The genetics of garden plants. 4th ed. Macmillan, London.

D robny, J. 1990. Genetical improvement of plums in Czechoslovakia. Acta H ort. 283:83-94.

D u, J.J., H .Y. Yang, and J.W. Chi. 1993. Preliminary report on selections of $C$ hinese $d$ warf cherry (in Chinese). China Fruits 1993(3):23-24.

D ucroquet, J.-P. 1994. Behavior of some South African plum cultivars in middle east of Santa Catarina state (in Portuguese). Rev. Bras. Frut., Cruz das Almas 16:207-214.

Duval, H., J.L. Poessel, and G. Olivier. 1994. Evaluation and selection of progeny of an interspecific crossbetween Prunusceras fera and Prunus salicina. Acta H ort. 359:87-92.

Eremin (Eryomine), G.V. 1991. N ew data on origin of Prunusdomettica L. Acta H ort. 283:2729.

Gomez, E. and C. Ledbetter. 1994. Comparative study of the aromatic profiles of two different plum species: Prunus salicina Lindl. and Prunus simonii L. J. Sci. Food Agr. 65:111-115.

Gomez, E., C.A. Ledbetter, and P.L. H artsell. 1993. Volatile compounds in apricot, plum, and their interspecific hybrids. J. Agr. Food Chem. 41:1669-1676.

H artmann, W. 1991. A clonal selection within the sharka tolerant plum cultivar 'Buhler Fruhzwetsche'. Acta H ort. 283:305-309. 
$\mathrm{H}$ artmann, W. 1994. Plum breeding at $\mathrm{H}$ ohenheim. Acta H ort. 359:55-62.

H ilaire, C. and R. Renaud. 1985. Prune: Study of new varieties, stage $A$ (in French). Infos-C tifl 16. ( $\mathrm{N} \mathrm{ov)}$.

$\mathrm{H}$ jeltnes, S.H . 1994. Plum breeding in N orwayPast, present and future. Acta H ort. 359:63-68.

H oward, W.L. 1945. L uther Burbank's plant contributions. Calif. Agr. Expt. Sta. Bul. 691.

I kase, L. 1992. Diploid hybrid plum breeding in L atvia. Proc. 1st Gen. Congr. Baltic States 3-4:6869.

J ones, R.P. and D. Wilson. 1987. Plum breeding, p. 125-133. In: A.J. Abbott and R.K. Atkin (eds.). I mproving vegetatively propagated crops. A cademic Press, N ew York.

Kadir, S.A. and E.L. Proebsting. 1994. Various freezing strategiesofflower-bud hardinessin Prunus J. Amer. Soc. H ort. Sci. 119:584-588.

Kataoka, I., A. Sugiura, and T. Tomana. 1988. Interspecific hybridization between Microcerasus and other Prunus spp. (in Japanese). J. Jpn. Soc. H ort. Sci. 56:398-407.

Kellerhals, M . and P. Rusterholz. 1994. Plumbreeding at Wadenswil. Acta H ort. 359:82-86.

Li, F. 1993. Promising hardy plum selections. China Fruits 1993 (1):1-2.

Nakasu, B.H., M. do Carmo Bassols, and A.J. Feliciano. 1981. Temperatefruit breeding in Brazil. Fruit Var. J. 35:114-122.

O gasanovic, D., M. Rankovic, R. Plazinic, and V. Papic. 1994. Performance of newly-bred Cacak plum cultivars and current breeding techniques. Acta H ort. 359:75-81.

Ojima, M., F.A. Campo-D all'O rto, W. Barbosa, and O. Rigitano. 1992. Plum cultivars for Sao Paolo state (in Portuguese). Inst. Agron. Campinas Bul. Tech. 144.

O kie, W.R. and J.H. Weinberger. 1996. Plums, p. 559-607 In: J. J anick and J.N . M oore (eds.). Fruit breeding. Wiley, N ew York.

Paunovic, A.S. 1988. Plum genotypes and their improvement in Yugoslavia. Fruit Var. J. 42:143151.

Paunovic, S.A., M. Gavrilovic, and P.D. Misic. 1975. The breeding and introduction of new plum selections. Acta H ort. 48:91-110.

Q uamme, H .A., R.E. C. Layne, and W.G. Ronald. 1982. Relationship of super cooling to cold hardiness and the northern distribution of several cultivared and native Prunus species and hybrids. Can. J. Plant Sci. 62:137-148.

Ramming, D.W. and V. Cociu. 1990. Plums, p. 233-287. In: J.N. M oore and J.R. Ballington, J r. (eds.). Genetic resources of temperate fruit and nut crops. Acta H ort. 290, vol. 1

Rankovic, M., D. Ogasanovic, and S. Paunovic.
1994. Breeding of plum cultivars resistant to sharka (plum pox) disease. Acta H ort. 359:69-74.

Ravelonandro, M., R. Scorza, J.C. Bachelier, G. Labonne, L. Levy, V. D amsteegt, A.M. Callahan, and J. D unez. 1997. Resistanceof transgenic Prunus dometica to plum pox virus infection. Plant Dis. 81:1231-1235.

Renaud, R. 1994. Fermareine, a new European plum variety. Acta H ort. 359:93-96.

Renaud, R. and M.Y. Roy. 1990. Selection and evaluation of hybridsissued from intraspecific crosses with Prunusdomestica. Acta H ort. 283:69-74.

Reynders-Aloisi, S. and F. G rellet. 1994. Characterization of the ribosomal DNA units in two related Prunus species ( $P$. cerasifera and $P$. spinosa). Plant Cell Rpt. 13:641-646.

R oach, F.A. 1985. Cultivated fruits of B ritain: Their origin and history. Blackwell, N ew York.

R ussell, D ., J . H eaton, and B. Topp. 1992. B acterial spot disease resistance breeding for J apanese plums. Proc. 1st N at. Conf. Austral. Soc. H ort. Sci. 295299

Scorza, R., S.A. M ehlenbacher, and G .A. Lightner. 1985. I nbreeding and co-ancestry of freestonepeach cultivars of the eastern U nited States and implications for peach germplasm improvement. J. Amer. Soc. H ort. Sci. 110:547-552.

Sherman, W.B. and P.M . Lyrene. 1985. Progressin low-chill plum breeding. Proc. Fla. State H ort. Soc. 98:164-165.

Sherman, W.B., B.L. T opp, and P.M . Lyrene. 1992. Japanese-type plums for subtropical climates. Acta H ort. 317:149-153.

Tehrani, G. 1990. Seventy-five years of plum breeding and pollen compatibility studies in Ontario. Acta H ort. 283:95-103.

Topp, B.L. and D.M. Russell. 1989. Breeding early ripening J apanese plums. Acta H ort. 240:27-30.

Topp, B.L. and W.B. Sherman. 1990. Potential for low-chill J apanese plums in Florida. Proc. Fla. State H ort. Soc. 103:294-298.

Topp, B.L., W.B. Sherman, R.E. Stall, and G.V. $M$ insavage. 1993. Comparison of greenhousemethods for assessing resistance to bacterial leaf spot in plum. J. Amer. Soc. H ort. Sci. 118:667-671.

Wight, W.F. 1915. Native American species of Prunus U SDA Bul. 179.

Wu, S.X. 1993. N ew plum variety Sui Li 3. Crop Gen. Resources 3:46-47.

Yoshida, M . 1987. The origin of fruits. II. Plums (in Japanese). Fruit J apan 42(2):49-53.

Zhang, J., Y. H e, T. Li, X. Pen, Z. Guo, and F. Li. 1990. N atural resources and geographic distribution of Prunus germplasm in China tropic and subtropic zones, p. 504-508. In: Proc. Intl. Symp. $\mathrm{H}$ ort. Germplasm, Cultivated and Wild. Chinese Soc. H ort. Sci., Bejing. 